\title{
Pneumocystis carinii Inhibits Cyclin-dependent Kinase Activity in Lung Epithelial Cells
}

\author{
Andrew H. Limper, Maryanne Edens, Robert A. Anders, and Edward B. Leof \\ Thoracic Diseases Research Unit, Division of Pulmonary, Critical Care, and Internal Medicine, Department of Medicine; and the \\ Department of Biochemistry and Molecular Biology, Mayo Clinic, Rochester, Minnesota 55905
}

\begin{abstract}
Pneumocystis carinii remains an important cause of pneumonia in patients with AIDS. Attachment of the organism to epithelial cells is a central event in establishing infection, impairing the growth potential of lung epithelial cells and thereby slowing repair. In light of investigations documenting a central role for cyclin-dependent kinases in controlling the cell cycle, we addressed the hypothesis that $P$. carinii inhibits epithelial cell growth by interfering with host epithelial cyclin-dependent kinase (cdk) activity. We observed that $P$. carinii significantly impaired growth of cultured mink lung epithelial cells, with effects observed after 48-72 h of treatment. However, the kinase activity associated with p34 $4^{c d c 2}$ or ${\mathrm{p} 33^{c d k 2}}$ was maximally inhibited as early as $24 \mathrm{~h}$ after $P$. carinii exposure. The inhibitory effect on cyclindependent kinase activity was mediated by the trophozoite form of $P$. carinii, in that highly purified trophozoites exerted marked inhibition of p34 ${ }^{c d c 2}$ activity. Growth impairment was similarly preceded by $P$. carinii-induced alteration in the state of epithelial cell p34 ${ }^{c d c 2}$ phosphorylation, with no change in $\mathrm{p} 34^{c d c 2}$ or $\mathrm{p} 33^{c d k 2}$ protein levels. These data strongly suggest that the antiproliferative activity of $P$. carinii on respiratory epithelium is mediated in part through modulation of the host cell cycle machinery. $(J$. Clin. Invest. 1998. 101:1148-1155.) Key words: Pneumocystis carinii • epithelium • cyclin-dependent kinase • cell cycle
\end{abstract}

\section{Introduction}

Pneumocystis carinii remains an important cause of life-threatening pneumonia in immunocompromised patients, particularly in those with AIDS, hematological or solid malignancies, organ transplantation, or inflammatory conditions treated with immunosuppressive agents or chronic corticosteroid therapy (1-5). Severe P. carinii pneumonia in patients with AIDS is associated with diffuse lung injury, representing the most frequent cause of acute respiratory failure requiring admission to the intensive care unit in these patients (6-8). In addition, re-

Address correspondence to Edward B. Leof, Ph.D., Thoracic Diseases Research Unit, 642C Guggenheim Building, Mayo Clinic and Foundation, Rochester, MN 55905. Phone: 507-284-5717; FAX: 507284-4521; E-mail: leof.edward@mayo.edu

Received for publication 16 May 1997 and accepted in revised form 8 January 1998.

J. Clin. Invest.

(C) The American Society for Clinical Investigation, Inc. 0021-9738/98/03/1148/08 \$2.00

Volume 101, Number 5, March 1998, 1148-1155

http://www.jci.org covery from $P$. carinii pneumonia is frequently prolonged, reflecting impairment of normal lung reparative mechanisms during this disorder. Despite this fact, pathogenic mechanisms of lung injury and suppressed lung repair remain poorly understood during this infection.

Recent investigations indicate that attachment of $P$. carinii to lung epithelial cells is a central component of the organism's life cycle (9-12). P. carinii trophozoites attach to lung epithelial surfaces by closely approximating their membranes with the host cell surface, without fusion or internalization of the organism $(12,13)$. In vitro experiments indicate that attachment of $P$. carinii to host cells promotes life cycle completion and proliferation of the organism $(14,15)$. Several cell lines have been reported to support $P$. carinii proliferation in culture, including Mv1Lu mink lung epithelial cells, A549 lung carcinoma cells, and HEL299 lung fibroblasts (16-19). Additional work in our laboratory further indicated that $P$. carinii attachment impairs the growth potential of cultured A549 lung epithelial cells in a process requiring cytoskeletal rearrangement of the organism (9). Similar impairment of lung cell proliferation in vivo may retard reepithelialization, and hence slow lung repair of denuded alveolar surfaces during severe $P$. carinii pneumonia.

The mechanisms by which $P$. carinii impairs lung cell proliferation are largely unknown, but very likely involve alterations in expression and/or activity of the host cell cycle machinery. Of particular importance are the cyclin-dependent kinases $(\mathrm{cdk})^{1} \mathrm{p} 34^{c d c 2}$ and $\mathrm{p} 33^{c d k 2}$, serine/threonine kinases required for the transition from $\mathrm{G} 2$ to $\mathrm{M}$ and for entry into $\mathrm{S}$ phase from G1 (20,21). Regulated cdk activity mediates normal cell cycle progression, and has been reported to mediate cell cycle arrest induced by a number of cytokines such as TGF- $\beta$ (22-24). Mink lung epithelial cells (Mv1Lu, CCL64) have proven to be a particularly useful cell line to evaluate regulation of cdk activity $(22,25)$. The activity of $\mathrm{p} 34^{c d c 2}$ and $\mathrm{p} 33^{c d k 2}$ is carefully regulated by specific activating and inhibitory phosphorylations (26-29). For instance, phosphorylation of p34 ${ }^{c d c 2}$ at threonine 161 by a cdk-activating kinase (CAK) is required for activation, while phosphorylation at threonine 14 or tyrosine 15 is inhibitory $(28,29)$. In that regard, associated alterations of epithelial cell cdk activity during $P$. carinii pneumonia have not been previously evaluated.

This investigation, therefore, was undertaken to address the following issues: $(a)$ to determine the extent to which $P$. carinii inhibits proliferation of mink lung epithelial cells in culture; $(b)$ to evaluate whether $P$. carinii-induced inhibition of lung epithelial growth is preceded by alterations in host cell cyclin-dependent kinase activity; and $(c)$ to investigate potential mechanisms associated with any alteration in lung epithelial cell cdk activity. We report herein that $P$. carinii impairs

1. Abbreviation used in this paper: cdk, cyclin-dependent kinase. 
growth of mink lung epithelial cells after $48-72 \mathrm{~h}$ of treatment. This impairment of growth is temporally preceded by a reduction in $\mathrm{p} 34^{c d c 2}$ and $\mathrm{p} 33^{c d k 2}$ kinase activity mediated by the trophozoite form of $P$. carinii. We further provide evidence that this reduction in $\mathrm{p} 34^{c d c 2}$ activity occurs through modification in $\mathrm{p} 34^{c d c 2}$ phosphorylation with no detected change in steadystate protein levels.

\section{Methods}

Materials. All reagents were from Sigma Chemical Co. (St. Louis, MO) unless otherwise specified. Mink lung epithelial cells (Mv1Lu, CCL64) were obtained from the American Type Culture Collection (Rockville, MD) and grown at $37^{\circ} \mathrm{C}$ in DMEM supplemented with $10 \%$ FBS (Summit Biotechnologies, Ft. Collins, CO). $\left[{ }^{3} \mathrm{H}\right]$ thymidine, $\left[{ }^{32} \mathrm{P}\right] \gamma-\mathrm{ATP}$, and $\left[{ }^{32} \mathrm{P}\right]$ orthophosphate were purchased from NEN Research Products (Boston, MA). A rabbit polyclonal antibody to the $\mathrm{COOH}$ terminus of the $c d c 2$ kinase ( $\mathrm{p} 34^{c d c 2}$ ) was generated as previously reported (23). Rabbit polyclonal antibody to $\mathrm{p} 33^{\text {cdk2 }}$ was the generous gift of Dr. W.J. Pledger (H. Lee Moffitt Cancer Center Research Institute, Tampa, FL.) Ciprofloxacin was kindly provided by Miles Pharmaceuticals, Inc. (West Haven, CT).

Preparation of Pneumocystis carinii. All investigations were approved by the institutional animal care and use committee. Harlan Sprague-Dawley rats were immunosuppressed with dexamethasone and pneumonia produced by transtracheal injection with $P$. carinii $(9$, 30). Pathogen-free rats were given drinking water containing dexamethasone $(2 \mathrm{mg} / \mathrm{liter})$, tetracycline $(500 \mathrm{mg} / \mathrm{liter})$, and nystatin $(200,000$ U/liter) and fed a low-protein diet (8\%; Teklad Premier Laboratory Diets, Madison, WI). Each week, the animals received oral ciprofloxacin $(0.45 \mathrm{~g} /$ liter $)$ on two consecutive days to reduce the incidence of bacterial infections $(30,31)$. After $5 \mathrm{~d}$ of immunosuppression, rats were transtracheally inoculated with $P$. carinii $(\sim 500,000$ cysts) prepared by homogenizing infected rat lung. Rats were suppressed for an additional 6-8 wk and were then killed. The lungs were homogenized in $50 \mathrm{ml}$ of HBSS containing 10,000 U penicillin/liter, 10,000 $\mu \mathrm{g}$ streptomycin/liter, and $25 \mu \mathrm{g}$ amphotericin/liter using a Stomacher laboratory blender (Tekmar Co., Cincinnati, OH). P. carinii were purified by differential filtration in which the homogenates were exhaustively filtered through $10-\mu \mathrm{M}$ filters that retain lung cells, but allow passage of $P$. carinii. The filtrates were collected and centrifuged $(1,500 \mathrm{~g}$ for $30 \mathrm{~min}$ ), and the pellets were suspended in $5 \mathrm{ml}$ of HBSS. Duplicate 10- $\mu \mathrm{l}$ aliquots of suspension were spotted onto slides and stained with modified Wright-Giemsa (Diff Quick, Dade Diagnostics, Aquada, Puerto Rico), and P. carinii was quantified as described $(10,32)$. If other microorganisms were noted in the smear or on microbiologic culture, the material was discarded. These preparations contain a mixture of trophozoite and cyst forms in a typical ratio of 9:1 (trophozoites to cysts). To exclude further the possibility of endotoxin contamination, purified $P$. carinii isolates were also assayed for endotoxin using a modified Limulus amebocyte lysate assay (Whittaker M.A. Bioproducts, Inc., Walkersville, MD) with a lower limit of sensitivity of $0.125 \mathrm{U} / \mathrm{ml}$. $P$. carinii preparations shown to inhibit epithelial cell growth were also free of soluble endotoxin using this assay.

In selected experiments, differential filtration was used to separate $P$. carinii trophozoites from the cystic form (18). In brief, $P$. carinii cysts are retained by a $3-\mu \mathrm{m}$ nucleopore filter and resuspended after washing. $P$. carinii trophozoites, however, pass through the device and are collected by centrifugation. Use of this method in our laboratory has yielded trophozoite preparations containing $>99.5 \%$ pure trophozoites. The residual cyst populations are more than 40 -fold enriched for $P$. carinii cysts.

Effect of P. carinii on growth of lung epithelial cells. The cyclindependent kinase system has been well-characterized in mink lung epithelial cells $(22,25)$. In addition, these cells are established to support the viability of $P$. carinii in culture (19). Therefore, we evaluated the effect of $P$. carinii on growth of mink lung epithelial cells by de- termining total cell counts after incubating the lung cells with the organisms. Mink lung epithelial cells $\left(2 \times 10^{5}\right)$ were plated onto 6-well dishes $\left(9.6 \mathrm{~cm}^{2}\right)$ in $2 \mathrm{ml}$ of DMEM containing $10 \%$ FBS and $10,000 \mathrm{U}$ penicillin/liter, 10,000 $\mu \mathrm{g}$ streptomycin/liter, and $25 \mu \mathrm{g}$ amphotericin/ liter. After $24 \mathrm{~h}$ of incubation, $P$. carinii were directly added at the indicated concentrations, and the cells were cultured for an additional 0-72 h. Total cell counts were performed at 24-h intervals with an hemacytometer on triplicate wells in a blinded manner after removal with $\mathrm{Ca}^{2+} / \mathrm{Mg}^{2+}$-free PBS containing trypsin $(2 \mu \mathrm{g} / \mathrm{ml})$ and EDTA $(0.2 \mathrm{mg} / \mathrm{ml})$.

To determine whether $P$. carinii was inhibiting epithelial cell growth by exerting a generalized toxic effect on mink lung epithelial cells, epithelial cell viability was determined in additional assays after culture with $P$. carinii organisms. To accomplish this, mink lung epithelial cells were cultured in the presence of $P$. carinii at a ratio of 100:1 over $72 \mathrm{~h}$. Subsequently, the epithelial cells were removed with trypsin and enumerated. Mink lung epithelial cell viability was assessed by vital dye exclusion using $0.2 \%$ Trypan blue solution in $0.81 \%$ sodium chloride and $0.06 \%$ potassium phosphate dibasic. The percentage of viable cells that excluded Trypan blue was determined by counting 200 cells for each culture condition, performed in quadruplicate.

Assessment of epithelial cell cyclin-dependent kinase activity. To determine the effects of $P$. carinii on cyclin-dependent kinase activity in host epithelial cells, in vitro kinase assays were performed after culture in the presence or absence of the organism. Mink lung epithelial cells $\left(3 \times 10^{5}\right)$ were plated in $4 \mathrm{ml}$ of DMEM containing $10 \%$ FBS in 60 -mm tissue culture dishes $\left(22 \mathrm{~cm}^{2}\right)$ for $24 \mathrm{~h}$. $P$. carinii were added at the indicated concentrations, and the cells were incubated for an additional $24-48 \mathrm{~h}$. Subsequently, the cultures were harvested by trypsinization $\left(37^{\circ} \mathrm{C}\right.$ for $\left.10 \mathrm{~min}\right)$, and the cells were pelleted by lowspeed centrifugation ( $400 \mathrm{~g}$ for $5 \mathrm{~min}$ at $4^{\circ} \mathrm{C}$ ). Under these conditions, the pellet contains the host epithelial cells, while the $P$. carinii remain suspended (9). Cyclin-dependent kinase activity was determined on the cellular pellet as previously described $(23,33)$. In brief, the cell pellet was lysed on ice in $50 \mathrm{mM}$ Tris $(\mathrm{pH} 7.4)$ containing $250 \mathrm{mM}$ $\mathrm{NaCl}, 0.1 \%$ Triton X-100, $5 \mathrm{mM}$ EDTA, $50 \mathrm{mM} \mathrm{NaF}, 0.1 \mathrm{TIU} / \mathrm{ml}$ aprotinin, $50 \mu \mathrm{g} / \mathrm{ml}$ PMSF, $0.1 \mathrm{mM}$ sodium vanadate, and $1 \mu \mathrm{g} / \mathrm{ml} \mathrm{leu}$ peptin (final volume of 500-700 $\mu \mathrm{l}$ ). The insoluble material was pelleted at $15,840 \mathrm{~g}$ for $10 \mathrm{~min}$ at $4^{\circ} \mathrm{C}$, and total protein concentration was determined using the bicinchoninic acid method (BCA reagent; Pierce Chemical Co., Rockford, IL). $50 \mu \mathrm{g}$ of total cellular lysate was precleared for $20 \mathrm{~min}$ at $4^{\circ} \mathrm{C}$ with formalin-fixed Staph A before immunoprecipitation at $4^{\circ} \mathrm{C}$ for $2 \mathrm{~h}$ with a rabbit polyclonal antibody to the $\mathrm{COOH}$ terminus of the $\mathrm{Cdc} 2\left(\mathrm{p} 34^{c d c 2}\right)$ or $\mathrm{Cdk} 2\left(\mathrm{p} 33^{c d k 2}\right)$ kinase. Antibody complexes were precipitated with protein A sepharose, and an in vitro kinase assay was performed in a $50-\mu l$ reaction consisting of kinase buffer ( $50 \mathrm{mM}$ Tris, $10 \mathrm{mM} \mathrm{MgCl}_{2}, 1 \mathrm{mM} \mathrm{DTT}$, pH 7.4) supplemented with $5 \mu \mathrm{M}$ cold ATP, $5 \mu \mathrm{Ci}\left[{ }^{32} \mathrm{P}\right] \gamma$-ATP, and $100 \mu \mathrm{g} / \mathrm{ml}$ histone $\mathrm{H} 1$ for $5 \mathrm{~min}$ at $30^{\circ} \mathrm{C}$. The kinase reaction was stopped by adding $2 \times$ Laemmli buffer, and was boiled for $5 \mathrm{~min}$. Phosphorylated histone $\mathrm{H} 1$ was resolved on $10 \%$ SDS-PAGE and visualized by autoradiography.

Determination of $p 34^{c d c 2}$ phosphorylation. The state of activation of cyclin-dependent kinases is carefully regulated by the presence of activating and inhibiting phosphorylations (26-29). Accordingly, additional experiments were performed to evaluate whether interactions of $P$. carinii with epithelial cells resulted in alterations of host p34 ${ }^{c d c 2}$ kinase phosphorylation. Mink lung epithelial cells $\left(3 \times 10^{5}\right)$ were plated in DMEM containing $10 \%$ FBS for 24 h. P. carinii were added, and the cells were cultured for an additional $24 \mathrm{~h}$ at $37^{\circ} \mathrm{C}$. During the final $4 \mathrm{~h}$ of culture, the media were removed and replaced with $1 \mathrm{ml}$ of phosphate-free medium containing 10\% dialyzed FBS and $500 \mu \mathrm{Ci}\left[{ }^{32} \mathrm{P}\right]$ orthophosphate. Cells were harvested, and $200 \mu \mathrm{g}$ of protein was immunoprecipitated with antibodies to $\mathrm{p} 34^{c d c 2}$ as described above, except that cellular lysis and washes were performed in RIPA buffer $(50 \mathrm{mM}$ Tris $\mathrm{pH} 8.0,0.5 \%$ deoxycholate, $1 \%$ Triton $\mathrm{X}-100,0.1 \%$ SDS, $50 \mathrm{mM} \mathrm{NaF}, 0.1 \mathrm{mM}$ Na vanadate, $75 \mu \mathrm{g} / \mathrm{ml}$ PMSF, 
$0.1 \mathrm{TIU} / \mathrm{ml}$ aprotinin, $1 \mu \mathrm{g} / \mathrm{ml}$ leupeptin, and $8 \mathrm{mM}$ iodoacetamide in PBS). The phosphorylated $\mathrm{p} 34^{c d c 2}$ was resolved on $10 \%$ SDS-PAGE and visualized by autoradiography.

Statistical analysis. All data are expressed as the mean \pm SEM from multiple experimental runs. Differences in measured variables from experiments containing multiple treatment groups were first assessed using ANOVA. Subsequently, differences among individual data groups were evaluated using Student's $t$ test. Statistical testing was performed on the Statview II statistical package (Abacus Concepts, Inc., Berkeley, CA) using a Macintosh IIci personal computer. Statistical differences were considered to be significant if $P$ was $<0.05$.

\section{Results}

P. carinii inhibits growth of cultured mink lung epithelial cells. P. carinii infection results in denudation of the epithelial lining in the alveolar space $(11,13)$. It has been proposed that net epithelial cell loss is a direct consequence of inhibitory effects of $P$. carinii on the proliferative potential of the lung epithelium. In that regard, previous studies have shown a similar cellular growth impairment when $P$. carinii is added to A549 lung carcinoma cells in vitro (9). To identify and characterize potential biochemical targets through which $P$. carinii affects host cellular proliferation, we determined the effect of $P$. carinii on the growth of Mv1Lu mink lung epithelial cells. This culture system has been extensively characterized as to the cyclindependent kinase activity responsible for regulated cell cycle traverse, and as such is an appropriate model to investigate the cellular response to $P$. carinii attachment $(19,22,25)$. As shown in Fig. 1, adding increasing amounts of $P$. carinii to Mv1Lu cells results in an apparent dose-dependent inhibitory trend in cellular growth. Moreover, once a P. carinii/ Mv1Lu cell ratio of 100:1 was attained, a statistically significant decrease in host cellular proliferation was observed. $P$. carinii (100:1) induced $39.2 \pm 4.0 \%$ growth inhibition of Mv1Lu cells after 48 h of $P$. carinii treatment $(P=0.018$ compared with 48 -h Mv1Lu cell growth without $P$. carinii). This level of growth in-

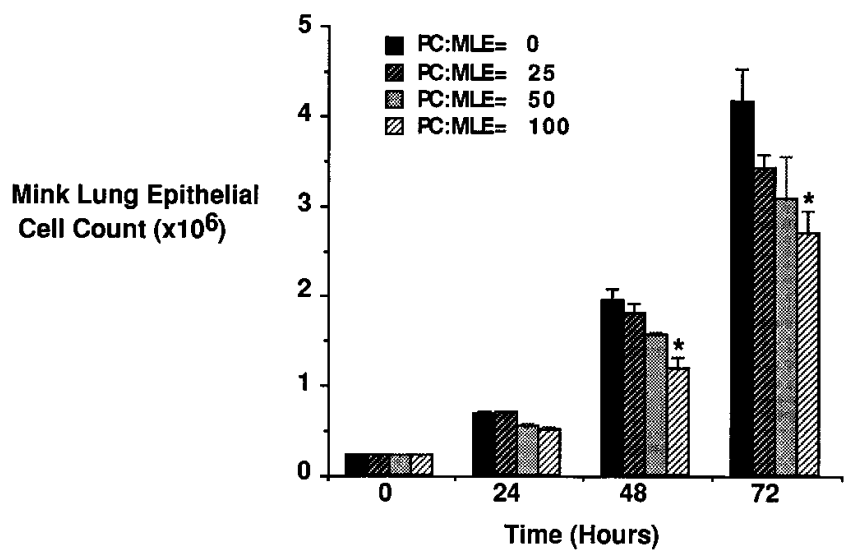

Figure 1. Growth impairment index of mink lung epithelial cells cultured in the presence of $P$. carinii. Mv1Lu cells were plated in six-well culture dishes at $2 \times 10^{5}$ cells/well in DMEM containing $10 \% \mathrm{FBS}$. After an overnight incubation at $37^{\circ} \mathrm{C}, P$. carinii was directly added to the culture to the indicated ratio of $P$. carinii/cells. Triplicate wells were counted over the next $3 \mathrm{~d}$. *Cell counts that are significantly different $(P<0.05)$ from the control wells containing no $P$. carinii at the same time point.

\section{Mink Lung Epithelial Cell}

Cdc2 Cdk2

\section{P. carinii Phosphorylated
H1 Histone} Immunoblot

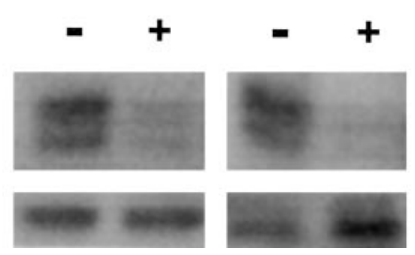

Figure 2. Effect of $P$. carinii on lung epithelial cell $\mathrm{p} 34^{c d c 2}$ and $\mathrm{p} 33^{c d k 2}$ kinase activity and protein level. After overnight incubation, mink lung epithelial Mv1Lu cells $\left(3 \times 10^{5}\right.$ cells $)$ were cultured in the absence (-) or presence (+) of $P$. carinii at a ratio of $P$. carinii to host cells of 100:1 for $24 \mathrm{~h}$. The top represents equivalent amounts of cellular protein extracted from $P$. carinii-treated and -untreated $\mathrm{Mv1Lu}$ cell cultures immunoprecipitated with antibodies to $\mathrm{p} 34^{c d c 2}$ (labeled $\mathrm{Cdc} 2$ ) or $\mathrm{p} 33^{\text {cdk2 }}$ (labeled Cdk2). The kinase activity associated with the immunoprecipitated products was determined by its ability to phosphorylate the substrate $\mathrm{H} 1$ histone. On the bottom, parallel plates were treated as described above, except that total p34 ${ }^{c d c 2}(\mathrm{Cdc} 2)$ or $\mathrm{p} 33^{\text {cdk } 2}(\mathrm{Cdk} 2)$ protein levels were examined by SDS-PAGE $(10 \mu \mathrm{g}$ protein each) and immunoblot analysis using antibodies specific for $\mathrm{p} 34^{c d c 2}(\mathrm{Cdc} 2)$ or $\mathrm{p} 33^{c d k 2}(\mathrm{Cdk} 2)$ proteins, respectively.

hibition induced by $P$. carinii (100:1) was maintained for an additional $24 \mathrm{~h}$ (35.2 $\pm 3.4 \%$ growth inhibition of Mv1Lu cells after 72 h, $P=0.034$; Fig. 1). After 24 h, the proportion of lung epithelial cells in the G0/G1 phase of the cell cycle was increased by $10 \%$ (data not shown). We have previously observed that $P$. carinii causes similar degrees of growth impairment for A549 human lung epithelial cells (9).

P. carinii inhibits $p 34^{c d c 2}$ and $p 33^{c d k 2}$ cyclin-dependent $k i$ nase activity in mink lung epithelial cells. Cell cycle traverse is regulated by the temporal activity of a family of cdks $(20,24$, 34). In general, cdk activity is low in quiescent cells. Once G1 traverse is initiated, however, distinct cyclin/cdk interactions are observed at defined cell cycle locations $(24,34)$. Two of the most extensively studied cdks include $\mathrm{p} 34^{c d c 2}$ and $\mathrm{p} 33^{c d k 2}$. The activity of both these kinases is required for optimal cell cycle traverse in a variety of cellular systems $(21,28)$. Since addition of $P$. carinii decreased the growth potential of Mv1Lu cells (Fig. 1), we wished to determine whether this decrease was similarly manifested in a decrease in $\mathrm{p} 34^{c d c 2}$ and/or p33 ${ }^{c d k 2} \mathrm{ki}$ nase activity. To perform these experiments, cycling Mv1Lu cells were incubated in the absence or presence of $P$. carinii, and the histone $\mathrm{H} 1$ kinase activity associated with $\mathrm{p} 34^{c d c 2}$ and p33 ${ }^{\text {cdk2 }}$ was determined. As shown in Fig. 2, 24-h treatment with $P$. carinii resulted in a $>70 \%$ decrease in the activity of both kinases. It should be noted that the inhibition in kinase activity observed after $24 \mathrm{~h}$ of $P$. carinii treatment (initiating at $12 \mathrm{~h}$ and maximal at 20-24 h; Fig. 2 and data not shown) precedes any significant effect on cell growth by 24-36 h (Fig. 1).

Decreased cdk activity can occur through a number of mechanisms (22-29). It was of paramount importance to determine whether this decrease in activity was simply a reflection of a decrease in the level of cdk protein. This question was directly addressed in Fig. 2 where immunoblot analysis was performed on $\mathrm{p} 34^{c d c 2}$ and $\mathrm{p} 33^{c d k 2}$ protein after $24 \mathrm{~h}$ of $P$. carinii treatment. The results show that while cdk kinase activity was 
decreased by adding $P$. carinii, there was no appreciable change in the steady-state protein level of either $\mathrm{p} 34^{c d c 2}$ or $\mathrm{p} 33^{c d k 2}$.

It is possible that $P$. carinii might suppress cyclin-dependent kinase activity through a generalized toxic effect of the organisms on the lung epithelial cells rather than by a specific effect on the epithelial cell cycle regulatory machinery. Several lines of evidence strongly argue against this possibility. First, although $P$. carinii induced a significant decrease in $\mathrm{p} 34^{c d c 2}$ or p33 ${ }^{c d k 2}$ activity, the organism did not decrease the levels of either of these proteins; only their functional status (Fig. 2). This result indicates that generalized cellular processes including protein synthesis are intact in cells challenged with $P$. carinii. Furthermore, mink lung cells continue to divide in the presence of $P$. carinii, albeit at a slower rate, providing further evidence that the cells are not diffusely injured by $P$. carinii (Fig. 1). As an additional approach, we assessed mink lung epithelial cell viability after culture with $P$. carinii by its ability to exclude the vital dye Trypan blue. Even after 72 h, epithelial cell viability was similar in cultures with and without $P$. carinii (90.2 $\pm 1.2 \%$ epithelial cell viablity with $P$. carinii compared with $92.1 \pm 0.4 \%$ in epithelial cells without $P$. carinii; $P=0.19$ ). Thus, the ability of $P$. carinii to suppress $\mathrm{p} 34^{c d c 2}$ or $\mathrm{p} 33^{c d k 2}$ activity appears to be a specific effect on the epithelial cell cycle regulatory machinery, and not the result of generalized cellular toxicity caused by the organism.

The previous data (Figs. 1 and 2) clearly document an association between decreased $\mathrm{p} 34^{c d c 2}$ and $\mathrm{p} 33^{c d k 2}$ kinase activity and cellular growth arrest. To begin investigating both the causal relationship as well as the associated mechanism(s) mediating this response, we initially focused our studies on the effect of $P$. carinii on host $\mathrm{p} 34^{c d c 2}$ activation because of its fundamental role in cell cycle traverse $(26,28,35)$. Since Fig. 1 showed a decrease in Mv1Lu cell growth with increasing amounts of $P$. carinii, we next determined whether a similar $P$. carinii dose dependence would be observed on p34 $4^{c d c 2}$ kinase activity (Fig. 3). At $P$. carinii to epithelial cell ratios of $<50: 1$, no appreciable effect on $\mathrm{p} 34^{c d c 2}$ kinase activity was seen. However, when those ratios exceeded 50:1 (e.g., 75-100:1), a significant decrease in $\mathrm{H} 1$ kinase activity was observed. Although these experiments do not show a direct causal relationship, it is of interest that the inhibitory effect of $P$. carinii on $\mathrm{p} 34^{c d c 2} \mathrm{ki}-$ nase activity has a similar dose-dependence as that seen for host cell growth (Figs. 1 and 3).

Attachment of $P$. carinii to lung epithelial cells is necessary for inhibition of epithelial $p 34^{c d c 2}$ kinase activity. Our prior studies indicate that $P$. carinii attachment to lung epitheial cells is an integral component in establishing infection. Therefore, we

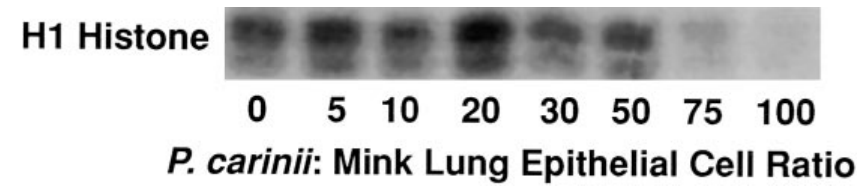

Figure 3. Dose-dependent inhibition of Cdc2 kinase activity of $P$. $c a-$ rinii. $\mathrm{Mv1Lu}$ epithelial cells were plated at $3 \times 10^{5}$ cells/well in $60-\mathrm{mm}$ tissue culture dishes $\left(9.6 \mathrm{~cm}^{2} /\right.$ well $)$ in DMEM supplemented with $10 \%$ FBS. After overnight incubation at $37^{\circ} \mathrm{C}$, the indicated ratio of $P$. carinii to epithelial cells was added, and $\mathrm{p} 34^{c d c 2}$ histone $\mathrm{H} 1$ kinase activity was determined $24 \mathrm{~h}$ later as described.

\section{Mink Lung Epithelial Cell Cdc2 Kinase}

\section{P. carinii \\ Phosphorylated H1 Histone}

\section{Cultured Without Cultured With Transwell Transwell}

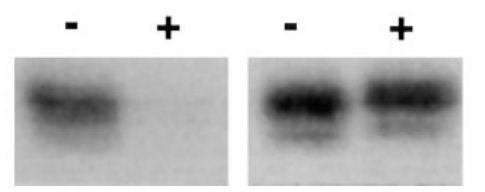

Figure 4. Attachment of $P$. carinii to epithelial cells is necessary for inhibition of epithelial cell p34 ${ }^{c d c 2}$ kinase activity. Mv1Lu epithelial cells were plated in DMEM supplemented with $10 \%$ FBS on 6-well plates. After $24 \mathrm{~h}$ of incubation at $37^{\circ} \mathrm{C}$, isolated Pneumocystis carinii were added (100:1; P. carinii to Mv1Lu cells) either directly onto the cell monolayers or to the upper chamber of a Transwell tissue culture insert that prevents organism attachment to the cells. After $24 \mathrm{~h}$, the epithelial cells were removed and extracted. Equivalent amounts of cellular protein extracted from $P$. carinii-treated and -untreated Mv1 Lu cell cultures $(100 \mu \mathrm{g})$ were immunoprecipitated with antibodies to $\mathrm{p} 34^{c d c 2}$. The kinase activity associated with the immunoprecipitated products was determined by its ability to phosphorylate the substrate H1 histone. P. carinii, permitted to directly interact with the cells, caused marked suppression of $\mathrm{p} 34^{c d c 2}$ kinase activity. In contrast, $P$. carinii that were prevented from attaching to the cells by the permeable Transwell membrane had no appreciable effect on mink lung epithelial cell p34 $4^{c d c 2}$ activity.

next questioned whether $P$. carinii binding to mink lung epithelial cells was necessary for $P$. carinii to suppress epithelial cell $\mathrm{p} 34^{c d c 2}$ kinase activity. We have recently shown that $P$. carinii can be cocultured with lung epithelial cells on the upper chamber of a permeable Transwell membrane (Becton Dickinson, Franklin Lakes, NJ), impairing growth of the organism $(14,15)$. Although the $P$. carinii organisms are not permitted to bind to the lung cells, they share the same media as the lung cells, and soluble components can pass freely through the membrane (0.4- $\mu \mathrm{M}$ pore size). Therefore, we used this system to address whether binding of $P$. carinii to host cells was necessary for inhibiting mink lung epithelial cell p34 $4^{c d c 2}$ activity. $P$. carinii were cultured either directly on epithelial cell monolayers, or in the upper chamber of a Transwell tissue culture insert that prevents organism attachment to the epithelial cells $(14,15)$. After $24 \mathrm{~h}$, the epithelial cells were removed and extracted. Equivalent amounts of cellular protein from P. cari$n i i$-treated and -untreated Mv1Lu epithelial cell cultures were immunoprecipitated with antibodies to $\mathrm{p} 34^{c d c 2}$, and the kinase activity associated with the precipitable products was determined (Fig. 4). As noted previously, $P$. carinii cultured in contact with epithelial cells $(P$. carinii/epithelial cell ratio of 100:1) markedly suppressed the ability of epithelial cell p34 ${ }^{c d c 2}$ to phosphorylate $\mathrm{H} 1$ histone substrate. However, an identical number of $P$. carinii prevented from adhering to the lung cells by the Transwell insert had no effect on the activity of epithelial cell $\mathrm{p} 34^{c d c 2}$. Therefore, direct binding of $P$. carinii to the lung epithelial cells is required for the observed impairment of cyclin-dependent kinase activity. This experiment further indicates that the mere presence of viable $P$. carinii or the release of a soluble toxin or host contaminant is not likely responsible for the observed suppression of lung epithelial cell p34 $4^{c d c 2}$ activity in these studies. 

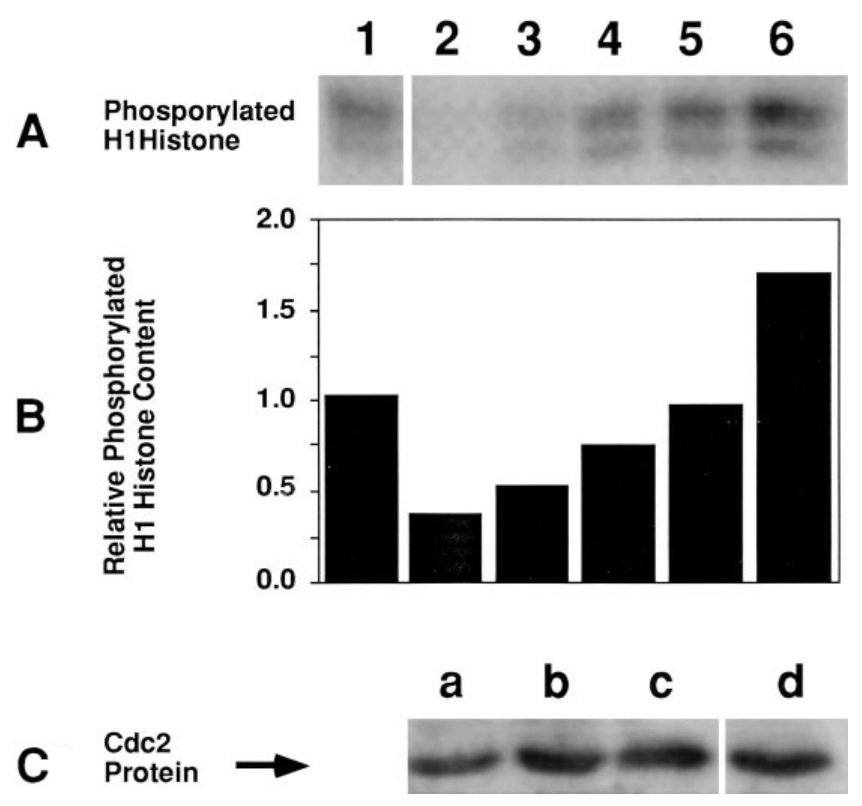

Figure 5. Effect of isolated $P$. carinii trophozoites on mink lung epithelial cell p34 ${ }^{c d c 2}$ kinase activity. Mv1Lu epithelial cells were plated as described in Fig. 3 in DMEM supplemented with 10\% FBS. After $24 \mathrm{~h}$ of incubation at $37^{\circ} \mathrm{C}$, highly purified Pneumocystis carinii trophozoites, prepared as described in Methods, were added at the indicated $P$. carinii to Mv1Lu epithelial cell ratio. $(A)$ The $\mathrm{p} 34^{c d c 2}$ (cdc2) kinase activity of the mink lung epithelial cells was assessed after $24 \mathrm{~h}$ of $P$. carinii treatment by determining the ability of immunoprecipitated mink lung epithelial cell extracts to phosphorylate the substrate $\mathrm{H} 1$ histone. Lane 1 is untreated cycling cultures, lanes 2-6 contain epithelial cells cultured with $P$. carinii trophozoites at $P$. carinii/epithelial cells ratios of $100,50,25,10$, and 5:1, respectively. (B) Densitometric analysis of the presented autoradiogram from $A$ with the kinase activity seen in untreated cycling cultures reported as 1.0. $(C)$ Total p34 $4^{c d c 2}$ (labeled Cdc2) protein in samples from $A$ was determined by immunoblot analysis. Lanes $a, b, c$, and $d$ demonstrate the level of Mv1Lu epithelial cell cdc2 protein level after culture with $P$. carinii trophozoites at ratios of 100,50,25, and 5:1, respectively.

Isolated P. carinii trophozoites mediate inhibition of mink lung cell epithelial p34cdc2 kinase activity. Previous studies in human and animal tissues have revealed that the life cycle of $P$. carinii consists of both the more numerous trophozoite forms (1-2 $\mu \mathrm{m})$, and larger cystic forms $(8 \mu \mathrm{m})$, containing a characteristic $\beta$-glucan-rich wall $(11,13)$. Adherence of the trophozoite form to the host cell membrane is necessary for completion of the fungal life cycle and subsequent effects on the lung epithelium $(9,10,14,15)$. Our earlier studies indicate that trophozites adhere to lung epithelial cells by interdigitation of their cellular membranes with those of the host cell (9). Figs. 1-4 document that mixed isolates of trophozoites and cyst forms of $P$. carinii (in a ratio of roughly 9:1 trophozoites/cysts) suppress host cyclin-dependent kinase activity and epithelial cell growth. Next, we further examined whether purified preparations containing essentially only trophozoites could also mediate this process. To investigate this, $P$. carinii isolates were further separated into isolated trophozoite preparations by differential filtration. Examinations of $P$. carinii preparations before and after differential filtration using modified Wright-Giemsa and methenamine silver stains revealed the trophozoite preparations to contain $>99.5 \%$ trophozoites.
Subsequently, the effects of isolated trophozoites on p34 $4^{c d c 2}$ activity were determined (Fig. 5). As shown in Fig. $5 \mathrm{~A}$, as the ratio of trophozoites to host cells was increased, there was a dose-dependent inhibition in host cell $\mathrm{p} 34^{\text {cdc }}$ kinase activity on histone $\mathrm{H} 1$ substrate in a manner similar to that observed with unfractionated $P$. carinii (Fig. 3). In fact, the inhibitory response with purified trophozoites was approximately $2-3$ fold more sensitive when compared with the mixed $P$. carinii cultures containing both cysts and trophozoites (Fig. 3 and Fig. 5, $A$ and $B$ ). Again, similar to that observed in Fig. 2 with unfractionated $P$. carinii, the isolated $P$. carinii trophozoite preparations had no detectable effect on total $\mathrm{p} 34^{d c 2}$ protein levels, even at higher concentrations (Fig. $5 C$ ). Thus, we observed that highly purified $P$. carinii trophozoites exhibit marked inhibition of lung epithelial cell p34 $4^{c d c 2}$ activity, but have no effect on the corresponding level of protein expression.

$P$. carinii alter the phosphorylation state of lung epithelial cell cdc2 kinase. The activity of $\mathrm{p} 34^{c d c 2}$ is regulated by a number of post-translational modifications (22-29, 35). For instance, while phosphorylation of $\mathrm{p} 34^{c d c 2}$ by a CAK on threonine 161 is required for activity $(27,35)$, phosphorylation on tyrosine 15 is inhibitory (29). Since the previous data (Figs. 2-4) showed an inhibition in kinase activity with no associated change in total protein, this suggested that $P$. carinii might inhibit cdk activity through a post-translational mechanism. To address that question, Mv1Lu cells were metabolically labeled with $\left.{ }^{[2} \mathrm{P}\right]$ orthophosphate after $24-\mathrm{h}$ treatment in the presence or absence of $P$. carinii, and the effect on $\mathrm{p} 34^{\text {cdc } 2}$ phosphorylation was determined (Fig. 6). A shift in $\mathrm{p} 34^{c d c 2}$ protein to a less

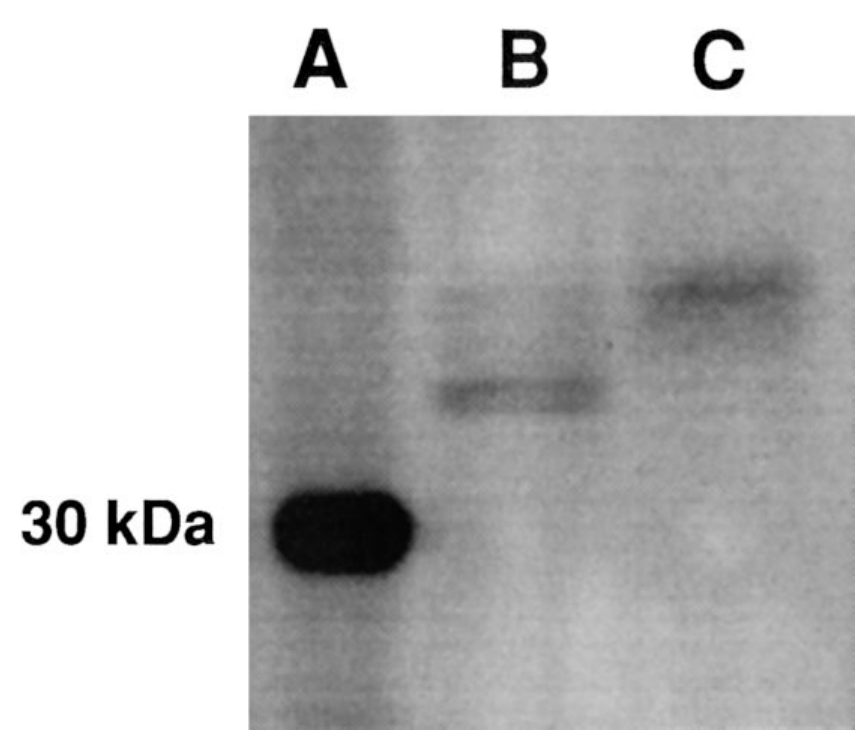

Figure 6. Phosphorylation of mink lung epithelial cell p34 $4^{\text {cdc2 }}$ is altered by $P$. carinii. Cells were plated as described in Fig. 3 and Methods. After a 24 -h incubation in the absence (lane $B$ ) or presence (lane $C$ ) of a 100:1 ratio of $P$. carinii to Mv1Lu epithelial cells, the culture was metabolically labeled with $\left[{ }^{32} \mathrm{P}\right]$ orthophosphate during the last $4 \mathrm{~h}$ of culture, and harvested. Equal cellular protein was immunoprecipitated with antibodies to $\mathrm{p} 34^{c d c 2}$ and analyzed by SDS-PAGE and autoradiography. The more mobile bands (lane $B$ ) indicate phosphorylation of threonine 161 associated with active $\operatorname{cdc} 2$, while the less mobile band (lane $C$ ) is consistent with phosphorylation of tyrosine 15 known to inactivate cdc2 kinase activity. Lane $A$ contains a molecular weight standard at $30 \mathrm{kD}$. 
mobile form was observed after treatment with $P$. carinii organisms. This decrease in $\mathrm{p} 34^{c d c 2}$ migration has been previously shown to correspond with the inactive tyrosine 15 phosphorylated form of the protein (29), and is consistent with the lack of functional kinase activity observed after $P$. carinii treatment (Figs. 2-5).

\section{Discussion}

$P$. carinii causes diffuse alveolar damage and respiratory failure with prolonged lung repair in a subset of patients with pneumonia. Mechanisms mediating this lung injury are not fully known, but likely incorporate both direct effects from the organisms as well as the adverse effects of neutrophilic lung inflammation that accompanies severe infection $(1,13,36)$. Recovery and repair of lung injury in these patients is frequently prolonged, requiring several weeks of intensive therapy (6). $P$. carinii-induced impairment of lung epithelial cell growth may be responsible for the sluggish repair of clinically observed lung injury during $P$. carinii pneumonia. Further understanding of $P$. carinii-induced alterations in lung cell proliferation may yield additional new insights to enhance lung repair during this infection. To that end, the data in the present manuscript indicate that $P$. carinii inhibits proliferation of mink lung epithelial cells. Furthermore, epithelial growth inhibition is preceded by $P$. carinii-induced alterations in cyclin-dependent kinases that regulate cell cycle traverse. As early as $12-24 \mathrm{~h}$ after addition of $P$. carinii, mink lung epithelial cells exhibited alterations in $\mathrm{p} 34^{c d c 2}$ and $\mathrm{p} 33^{c d k 2}$ kinase activity and $\mathrm{p} 34^{c d c 2}$ phosphorylation necessary for normal progression through the cell cycle. As anticipated, molecular inhibition of cell cycle progression occurred before the observed reduction in cell growth observed between 48 and $72 \mathrm{~h}$. These findings strongly suggest that alterations of cyclin-dependent kinase activity represent a potential molecular target mediating the antiproliferative activity of $P$. carinii on host respiratory epithelia.

It is of interest that the observed effect of $P$. carinii on lung epithelial cell cyclin-dependent kinase activity exhibited a threshold effect. At $P$. carinii/epithelial cell ratios of $<50: 1$, no appreciable effect on p34 ${ }^{c d c 2}$ kinase activity was seen. However, when those ratios exceeded 50:1, a significant decrease in H1 kinase activity was observed. A similar dose dependence was documented for host cell growth. Stepwise inductions of cell activation have been observed in other studies of $P$. carinii (37). It should be noted that $P$. carinii trophozoties are quite small ( $\sim 1-2 \mu \mathrm{m}$ in diameter), while the mink lung epithelial cells are appreciably larger $(\sim 30 \mu \mathrm{m}$ in diameter). Our prior studies indicate that $35-40 \%$ of $P$. carinii bind to epithelial cells in culture (9). These data also indicate that direct attachment of $P$. carinii to lung cells is necessary for the observed reduction in mink lung epithelial cell cdk activity (Fig. 4). Therefore, a concentration of $50 P$. carinii to each lung epithelial cell is consistent with the majority of the epithelial cell surfacebinding $P$. carinii organisms.

Previous studies have supported the contention that the attachment of $P$. carinii to host epithelial cells is of differential consequence to the host and the organism. Our prior studies in A549 cells similarly indicated that $P$. carinii could impair the growth of a transformed lung epithelial cell line in culture (9). That study further demonstrated that the effect of $P$. carinii on the host required direct contact of the organism, and was not transmissible by conditioned media. Furthermore, prior inhibi- tion of $P$. carinii with agents that inhibited cytoskeletal functions prevented binding of the organisms to the lung cells, and reversed epithelial growth impairment $(9,11)$. Unfortunately, cytoskeletal agents themselves alter basal levels of epithelial cell cdk activity, and were therefore not testable in the current study. Previous ultrastructural studies have further suggested that lung epithelial cells display vacuolization in regions of $P$. carinii attachment $(12,13)$. Taken together, these studies indicate that binding of $P$. carinii to lung epithelial cells exerts substantive deleterious effects upon the host.

In contrast to the previously described deleterious effects on the host, most investigations indicate that attachment of $P$. carinii to the alveolar epithelium is of net benefit to the organism. Binding of $P$. carinii to host epithelial cells has been consistently observed in lungs from both humans and animals with $P$. carinii during initiation of pneumonia $(12,13)$. In addition, proliferating $P$. carinii closely binds to epithelial cells in tissue culture in a manner closely mimicking that observed in vivo $(10,16)$. Recent studies additionally demonstrate that binding of $P$. carinii to epithelial cells promotes life cycle completion and organism proliferation $(14,15)$. What the organism derives from this intimate interaction with host cells is currently a matter of conjecture, although electron micrographic analyses have suggested that the epithelium provides a surface on which $P$. carinii conjugation and genetic exchange may occur (38). Moreover, the alveolar epithelial surface is particularly rich in host proteins and surfactant components that may provide unique moieties absorbed and used by the organisms (39-44). An additional possibility is suggested by the recent report that Trypanosoma cruzii uses host cell signal transduction pathway intermediates (45). Whether $P$. carinii uses a similar signaling mechanism is presently unknown. However, we have performed preliminary studies examining whether $P$. carinii uses a signaling pathway similar to that activated by the growth inhibitory cytokine TGF $\beta$. In contrast to the results observed for Trypanosoma cruzii, adding $P$. carinii to Mv1Lu cells suppressed luciferase activity from a TGF $\beta$-regulated reporter construct (unpublished observations). Clearly, additional investigations will be necessary to explore these hypotheses further.

Our current study reveals a potential mechanism by which $P$. carinii binding inhibits cell cycle progression in the host epithelium. The eukaryotic cell cycle is precisely regulated by a number of cell division cycle control proteins of which $\mathrm{p} 34^{c d c 2}$ is of primary importance. This protein serine/threonine kinase is needed for the transition from G2 to $\mathrm{M}$, and for entry into S phase from G1 at a site known as START in fungi. Activity of the $\mathrm{p} 34^{c d c 2}$ protein is sequentially controlled by a variety of positive- and negative-acting signals. For instance, activation of the kinase requires association with a regulatory cyclin molecule as well as both removal of negative-acting phosphorylations (e.g., tyrosine 15) and addition of positive-acting phosphorylations (e.g., threonine 161/167; 29). Cdc25, a tyrosine phosphatase, is responsible for removal of inhibitory phosphorylation on tyrosine $15(29,46,47)$. Our current study indicates that attachment of $P$. carinii to respiratory epithelial cells alters both the phosphorylation state (and hence the protein kinase activity of lung epithelial cell p34 $4^{c d c 2}$ ) and the kinase activity of p33 $3^{c d k 2}$ (Figs. 2 and 6). Most importantly, these modifications occur independently of any change in total cdk protein level without any decrease in epithelial cell viability, and occur significantly earlier than the observed suppression in lung cell 
growth (Figs. 1 and 2). The finding that the inhibitory effects on cdk activity precedes the observed decrease in lung cell growth by $24 \mathrm{~h}$ indicates $(a)$ that the lack of cyclin-dependent kinase activity is not just a reflection of the growth inhibitory state; and $(b)$ that the inhibitory effects on these cell cycle control proteins may be the biochemical targets with which $P$. carinii modulates proliferation of the host epithelium.

The exact molecular mechanisms by which $P$. carinii decreases epithelial cell cyclin-dependent kinase activity and proliferation are not yet fully known. Our data indicate in part that alteration of $\mathrm{p} 34^{c d c 2}$ activity is accompanied by changes in its state of phosphorylation. Other studies also indicate that cyclin-dependent kinase activity can be regulated by potent inhibitory proteins, most notably the Cip/Kip and Ink4 families of inhibitors (48-50). Information is not yet available as to the expression and activity of such cyclin-dependent kinase inhibitory proteins in lung epithelial cells after interaction with $P$. carinii.

Our findings of the suppressive effects of $P$. carinii on lung epithelial cell cycle progression through decreased epithelial cell $\mathrm{p} 34^{c d c 2}$ activity may further explain the sluggish repair of injured pulmonary tissue and slow restoration of respiratory function that has been observed in severe Pneumocystis pneumonia in man (6). Despite effective drugs, severe $P$. carinii infection can be associated with diffuse alveolar damage, widespread loss of respiratory epithelium, and markedly delayed recovery of normal gas exchange. Ultrastuctural studies indicate that $P$. carinii binds predominantly to Type I cells that cover the majority of the alveolar epithelial surface area (51). Additional studies also reveal that $P$. carinii adhere in a similar manner to progenitor type II cells (12). Type I cells are terminally differentiated cells incapable of further division. Reepithelialization of injured alveolar surfaces, therefore, requires proliferation and differentiation of Type II cells. Binding of $P$. carinii to proliferating alveolar epithelial cells with impairment of cell cycle progression would therefore impede restoration of a functioning epithelial surface and return of normal gas exchange.

Finally, we observed that the inhibitory effects of $P$. carinii on cdk activity were mediated by the isolated trophozoite form of the organism's life cycle (Fig. 4). This result supports earlier observations that trophozoites are the life form that actively attaches to alveolar epithelium through membrane reorganization $(9,11,13)$. Additional investigations indicate that $P$. carinii trophozoites themselves contain greater organismal Cdc2 activity than do cysts, and that trophozoite binding to epithelial cells promotes $P$. carinii proliferation $(10,14-16,52)$. Thus, $P$. carinii trophozoites appear to represent the more metabolically active replicative form of the organism.

In summary, we have demonstrated that $P$. carinii significantly inhibits the growth of a cultured lung epithelial cell line. Growth inhibition of mink lung epithelial cells was temporally preceded by decreases in the protein kinase activity of $\mathrm{p} 34^{c d c 2}$ and $\mathrm{p} 33^{c d k 2}$ independently of changes in epithelial cell viability or total cdk protein levels. Furthermore, a potential mechanism for the decrease in $\mathrm{p} 34^{c d c 2}$ kinase activity is suggested by the apparent increase in the inhibitory phosphorylation at tyrosine 15 after $P$. carinii treatment. This ability of $P$. carinii to impair lung epithelial growth may further delay healing and repair of alveolar injury during severe infection. Understanding the mechanisms that control epithelial cell growth suppression may ultimately yield new potential $P$. carinii pneumonia therapies.

\section{Acknowledgments}

We thank Mr. Joseph Standing and Drs. Charles Thomas and Zvezdana Vuk-Pavlovic for their assistance with production of $P$. $c a$ rinii and for many helpful discussions. The authors appreciate the kind gift of ciprofloxacin from Ms. Barbara Painter of Miles Pharmaceuticals, Inc. We further thank Ms. Kathy Stanke for her assistance in the final preparation of the manuscript.

This work was supported by National Institutes of Health grants R01-HL55934, R01-CA59883, R01-GM54200, R01-HL557125, and R29AI34336. We appreciate the kind gift of rabbit polyclonal antibody recognizing $\mathrm{p} 33^{c d k 2}$ from W.J. Pledger (H. Lee Moffitt Cancer Research Institute, Tampa, FL).

\section{References}

1. Limper, A.H., K.P. Offord, T.F. Smith, and W.J. Martin. 1989. Pneumocystis carinii pneumonia: differences in lung parasite number and inflammation in patients with and without AIDS. Am. Rev. Respir. Dis. 140:1204-1209.

2. Safrin S. 1993. Pneumocystis carinii pneumonia in patients with the acquired immunodeficiency syndrome. Sem. Respir. Infect. 8:96-103.

3. Yale, S.H., and A.H. Limper. 1996. Pneumocystis carinii pneumonia in patients without acquired immunodeficiency syndrome: associated disorders and prior corticosteroid therapy. Mayo Clin. Proc. 71:5-13.

4. Kovacs, J.A., J.W. Hiemenz, A.M. Macher, D. Stover, H.W. Murray, J. Shelhamer, H.C. Lane, C. Urmacher, C. Honig, and D.L. Longo. 1984. Pneumocystis carinii pneumonia: a comparison between patients with the acquired immunodeficiency syndrome and patients with other immunodeficiencies. Ann. Intern. Med. 100:663-671.

5. Gallant, J.E., R.D. Moore, and R.E. Chaisson. 1995. Prophylaxis for opportunistic infections in patients with HIV infection. Ann. Intern. Med. 122: 932-944.

6. Brooks, K.R., R. Ong, R.S. Spector, and D.M. Greenbaum. 1993. Acute respiratory failure due to Pneumocystis carinii. Crit. Care Clin. 9:31-48.

7. Gagnon, S., A.M. Boota, M.A. Fischl, H. Baier, O.W. Kirsky, and L. La Voei. 1990. Corticosteroids as adjunctive therapy for severe Pneumocystis carinii pneumonia in AIDS. A double blind placebo controlled trial. N. Engl. J. Med. 323:1444-1450.

8. Wachter, R.M., J.M. Luce, and P.C. Hopewell. 1992. Critical care of patients with AIDS. J. Am. Med. Assoc. 267:541-547.

9. Limper, A.H. and W.J. Martin. 1990. Pneumocystis carinii: inhibition of lung cell growth mediated by parasite attachment. J. Clin. Invest. 85:391-396.

10. Cushion, M.T., J.J. Ruffolo, M.J. Linke, and P.D. Walzer. 1985. Pneumocystis carinii: growth variables and estimates in the A549 and WI-38 VA13 human cell lines. Exp. Parasitol. 60:43-54.

11. Limper, A.H. 1991. Parasite adherence and host responses in the development of Pneumocystis carinii pneumonia. Sem. Respir. Infect. 6: 19-26

12. Long, E.G., J.S. Smith, and J.L. Meier. 1986. Attachment of Pneumocystis carinii to rat pneumocytes. Lab. Invest. 54:609-615.

13. Campbell, W.G. 1972. Ultrastructure of Pneumocystis in human lung. Arch. Pathol. 93:312-330.

14. Limper, A.H., C.F. Thomas, R.A. Anders, and E.B. Leof. 1997. Interaction of parasite and lung epithelial cell cycle regulation during Pneumocystis carinii pneumonia. J. Lab. Clin. Med. 130:132-138.

15. Limper, A.H., J.E. Standing, and E.B. Leof. 1995. Pneumocystis carinii adherence to alveolar epithelial cells promotes organism proliferation. J. Investig. Med. 43(Abstr.):466.

16. Cushion, M.T., and P.D. Walzer. 1984. Growth and serial passage of Pneumocystis carinii in the A549 cell line. Infect. Immun. 44:245-251.

17. Bartlett, M.S., P.A. Vervanac, and J.W. Smith. 1979. Cultivation of Pneumocystis carinii with WI-38 cells. J. Clin. Microbiol. 10:796-799.

18. Durkin, M.E., M.M. Shaw, M.S. Bartlett, and J.W. Smith. 1991. Culture and filtration methods for obtaining Pneumocystis carinii trophozoites and cysts. J. Protozool. 38:210-212.

19. Armstrong, M.Y.K., H. Koziel, R.M. Rose, C. Arena, and F.F. Richards. 1991. Indicators of Pneumocystis carnii viability in short term cell culture. J. Protozool. 38:88S-90S.

20. Pines, J. 1992. Cell proliferation and control. Curr. Opin. Cell Biol. 4: 144-148.

21. Guadagno, T.M., and J.W. Newport. 1996. Cdk2 kinase is required for entry into mitosis as a positive regulator of $\mathrm{Cdc} 2$-cyclin B kinase activity. Cell. 84:73-82.

22. Howe, P.H., G. Draetta, and E.B. Leof. 1991. Transforming growth factor $\beta 1$ inhibition of $\mathrm{p} 34^{\mathrm{cdc} 2}$ phosphorylation and $\mathrm{H} 1$ kinase activity is associated with G1/S phase growth arrest. Mol. Cell. Biol. 11:1185-1194.

23. Eblen, S.T., M.P. Fautsch, R.J. Burnette, P. Joshi, and E.B. Leof. 1994. Cell cycle-dependent inhibition of $\mathrm{p} 34^{\mathrm{cdc} 2}$ synthesis by transforming growth factor beta 1 in cycling epithelial cells. Cell Growth Differ. 5:109-116. 
24. Nurse, P. 1990. Universal control mechanism regulating onset of M-phase. Nature. 344:503-508.

25. Howe, P.H., M.R. Cunningham and E.B. Leof. 1990. Inhibition of mink lung epithelial cells proliferation by transforming growth factor beta is coupled through a pertussis-toxin-sensitive substrate. Biochem. J. 266:537-543.

26. Fleig, U.N., and K.L. Gould. 1991. Regulation of $c d c 2$ activity in Schizosaccharomyces pombe: the role of phosphorylation. Semin. Cell Biol. 2: 195-204.

27. Gould, K.L., S. Moreno, D.J. Owen, S. Sazer, and P. Nurse. 1991. Phosphorylation at Thr167 is required for Schizosaccharomyces pombe $\mathrm{p} 34^{\mathrm{cdc} 2}$ function. EMBO J. 10:3297-3309.

28. Norbury, C., J. Blow, and P. Nurse. 1992. Regulatory phosphorylation of the $\mathrm{p} 34^{\mathrm{cdc} 2}$ protein kinase in vertebrates. EMBO J. 10:3321-3329.

29. Honda, R., Y. Ohba, A. Nagata, H. Okayama, and H. Yasuda. 1993. Dephosphorylation of human $\mathrm{p} 34^{\mathrm{cdc} 2}$ kinase on both Thr-14 and Tyr-15 by human cdc25B phosphatase. FEBS Lett. 318:331-334.

30. Limper, A.H., J.S. Hoyte, and J.E. Standing. 1997. Alveolar macrophages mediate Pneumocystis carinii degradation and organism clearance from the lung. J. Clin. Invest. 99:2110-2117.

31. Pesanti, E.L., T. Tomicic, and S.T. Donta. 1991. Binding of ${ }^{125} \mathrm{I}$-labeled tumor necrosis factor to Pneumocystis carinii and an insoluble cell wall fraction. J. Protozool. 38:28S-29S

32. Limper, A.H., J.E. Standing, O.A. Hoffman, M. Castro, and L.W. Neese. 1993. Vitronectin binds to Pneumocystis carinii and mediates organism attachment to cultured lung epithelial cells. Infect. Immun. 61:4302-4309.

33. Anders, R.A., M. Gustafson, M. Edens, A.H. Limper, and E.B. Leof. 1996. Pneumocystis carinii modulates cyclin-dependent kinase activity in a lung epithelial cell line. J. Eukaryot. Microbiol. 43(Abstr.):13S

34. Norbury, C., and P. Nurse. 1992. Animal cell cycles and their control. Ann. Rev. Biochem. 61:441-470.

35. Morgan, D.O. 1995. Principles of CDK regulation. Nature. 374:131-134.

36. Mason, G.R., C.H. Hashimoto, P.S. Dickman, L.F. Faetty, and C.J. Cobb. 1989. Diagnostic implications of bronchoalveolar lavage neutrophilia in patients with Pneumocystis carinii pneumonia and AIDS. Am. Rev. Respir. Dis. 139:1336-1342.

37. Hoffman, O.A., J.E. Standing, and A.H. Limper. 1993. Pneumocystis carinii stimulates tumor necrosis factor- $\alpha$ secretion from alveolar macrophages through a $\beta$-glucan mediated mechanism. J. Immunol. 150:3932-3940.

38. Itatani, C.A. 1996. Ultrastructural morphology of intermediate forms and forms suggestive of conjugation in the life cycle of Pneumocystis carinii. $J$. Parasitol. 82:163-171.

39. Neese, L.W., J.E. Standing, E.J. Olson, M. Castro, and A.H. Limper.
1994. Vitronectin, fibronectin, and antibody to gp120 augment macrophage release of TNF-alpha in response to Pneumocystis carinii. J. Immunol. 152:45494556.

40. Phelps, D.S. and R.M. Rose. 1991. Increased recovery of surfactant protein A in AIDS-related pneumonia. Am. Rev. Respir. Dis. 143:1072-1075.

41. Zimmerman, P.E., D.R. Voelker, F.X. McCormack, J.R. Paulsrud, and W.J. Martin II. 1992. 120-kD surface glycoprotein of Pneumocystis carinii is a ligand for surfactant protein A. J. Clin. Invest. 89:143-149.

42. Limper, A.H. 1995. Adhesive glycoproteins in P. carinii pneumonia: host defense or microbial offense? J. Lab. Clin. Med. 125:12-13.

43. Pottratz, S.T., J. Paulsrud, J.S. Smith, and W.J. Martin. 1991. Pneumocystis carinii attachment to cultured lung cells by Pneumocystis gp120, a fibronectin binding protein. J. Clin. Invest. 88:403-407.

44. O'Riordan, D.M., J.E. Standing, K.Y. Kwon, D. Chang, E.C. Crouch, and A.H. Limper. 1995. Surfactant protein D interacts with Pneumocystis carinil and mediates organism adherence to macrophages. J. Clin. Invest. 95:26992710.

45. Ming, M., M.E. Ewen, and M.E. Pereira. 1995. Trypanosome invasion of mammalian cells requires activation of the TGF-beta signaling pathway. Cell. 82:287-296.

46. Moreno, S., P. Nurse, and P. Russell. 1990. Regulation of mitosis by the cyclin accumulation of $\mathrm{p} 80^{\text {cdc25 }}$ mitotic inducer in fission yeast. Nature. 344:549-552.

47. Dunphy, W.G., and A. Kumagai. 1991. The cdc25 protein contains an intrinsic phosphatase activity. Cell. 67:189-196.

48. Jones, D.L., R.M. Alani, and K. Munger. 1997. The human papillomavirus E7 oncoprotein can uncouple cellular differentiation and proliferation in human keritinocytes by abrogating p21Cip1-mediated inhibition of cdk2. Genes Dev. 11:2101-2111.

49. Reynisdottir, I., and J. Massagué. 1997. The subcellular localization of $\mathrm{p} 15^{\text {Ink4b }}$ and $\mathrm{p} 27^{\text {Kip } 1}$ coordinate their inhibitory interactions with cdk4 and cdk2. Genes Dev. 11:492-503.

50. Guan, K.L., C.W. Jenkins, Y. Li, C.L. O'Keefe, S. Noh, X. Wu, M. Zariwala, A.G. Matera, and Y. Xiong. 1996. Isolation and characterization of p19 ${ }^{\mathrm{INK} 4 \mathrm{~d}}$, a p16-related inhibitor specific to CDK6 and CDK4. Mol. Biol. Cell. 7: $57-70$.

51. Yoneda, K., and P.D. Walzer. 1983. Attachment of Pneumocystis carinii to type I alveolar epithelial cells by freeze-fracture electron microscopy. Infect. Immun. 40:812-815.

52. Thomas, C.F., M. Gustafson, Z. Vuk-Pavlovic, E.B. Leof, and A.H. Limper. 1996. Identification of a cell division cycle $(c d c 2)$ homologue in Pneumocystis carinii. J. Eukaryot. Microbiol. 43(5):11S. 